Journal of Telenursing (JOTING)

Volume 1, Nomor 2, Desember 2019

e-ISSN: 2684-8988

p-ISSN: 2684-8996

DOI: https://doi.org/10.31539/joting.v1i2.985

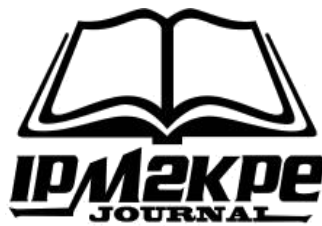

\title{
PENINGKATAN KEKUATAN OTOT PASIEN STROKE NON HEMORAGIK DENGAN HEMIPARESE MELALUI LATIHAN RANGE OF MOTION (ROM) PASIF
}

\author{
Elsi Rahmadani ${ }^{1}$, Handi Rustandi ${ }^{2}$ \\ Universitas Dehasen ${ }^{1,2}$ \\ elsirahmadani@yahoo.co.id ${ }^{1}$
}

\begin{abstract}
ABSTRAK
Penelitian ini bertujuan untuk Analisis Peningkatan Kekuatan Otot pada Pasien Stroke Non-Hemoragik dengan hemiparese melalui latihan pasif Range of Motion (ROM) di Rumah Sakit Curup Bengkulu 2019. Metode penelitian ini menggunakan desain Quasi Experiment desain pre dan post test design. Hasil penelitian ini menunjukkan nilai ratarata kekuatan otot pre-test dan post-test. meningkat pada kelompok intervensi dan tidak ada peningkatan pada kelompok kontrol. nilai signifikan $(\mathrm{p}=0,008)$ pada kelompok intervensi dan $(\mathrm{p}=0,5)$ pada kelompok kontrol. Simpulan, ada pengaruh latihan range of motion terhadap kekuatan otot pasien stroke non-hemoragik di Rumah Sakit Umum Curup ICU pada tahun 2019.
\end{abstract}

Kata Kunci: Kekuatan Otot, Latihan Range of Motion (ROM)

\section{ABSTRACT}

This study aims to analyze the strength of muscle strength in patients with nonhemorrhagic stroke with hemiparese through Passive Range of Motion (ROM) exercises at Bengkulu Curup Hospital 2019. This research method uses the Quasi Experiment design of the pre and post test designs. The results of this study indicate the average value of pre-test and post-test muscle strength. increased in the intervention group and no increase in the control group. significant value $(p=0.008)$ in the intervention group and $(p=0.5)$ in the control group. Conclusion, there is the effect of Range of Motion exercise on the muscle strength of non-hemorrhagic stroke patients at ICU Curup General Hospital in 2019.

Keywords: Muscle Strength, Range of Motion (ROM) Exercise

\section{PENDAHULUAN}

Stroke merupakan suatu kondisi yang digunakan untuk menjelaskan perubahan neurologik yang disebabkan oleh gangguan dalam sirkulasi darah ke bagian otak. Menurut American Heart Asso-ciation (2010) stroke menyumbang sekitar satu dari setiap 18 kematian di Amerika Serikat pada tahun 2006.

Stroke semakin menjadi masalah serius yang dihadapi hamper seluruh dunia. Stroke merupakan penyakit terbanyak ketiga setelah penyakit jantung dan kanker, serta merupakan penyakit penyebab kecacatan tertinggi di dunia. Menurut American Heart Association (AHA), di Amerika setiap tahunnya adalah 50-100 dari 100.000 orang penderita. Di Negara-negara ASEAN penyakit stroke juga merupakan masalah 
kesehatan utama yang menyebabkan kematian. Data South Asian Medical Information Centre (SEAMIC) menyebutkan bahwa angka kematian Stroke terbesar terjadi di Indonesia yang kemudian diikuti secara berurutan oleh Filipina, Singapura, Brunei, Malaysia, dan Thailand (Dinata, 2010).

Menurut WHO (2010) dalam jurnal Aini (2013) jumlah pendrita stroke di Indonesia berdasarkan sensus kependudukan dan demografi Indonesia (SKDI) tahun 2010 sebanyak 3.600 .000 setiap tahun dengan prevalensi 8,3 per 1.000 penduduk. Tahun 2020 diperkirakan 7,6 juta orang akan meninggal karena Stroke. Pada penderita Stroke 60,7\% disebabkan oleh stroke non hemoragik, sedangkan 36,6\% disebabkan oleh stroke hemoragik. Setiap tahunnya diperkirakan 500 ribu penduduk di Indonesia terkena serangan stroke (Yastroki, 2010). Riset Kesehatan Dasar (Riskesdas) tahun 2013 mendata kasus Stroke di wilayah perkotaan di 33 provinsi dan 440 kabupaten mengumpulkan sebanyak 258.366 sampel rumah tangga perkotaan dan 987.205 sampel anggota rumah tangga.

Di Indonesia, stroke merupakan penyebab kematian utama pada semua umur $(15,4 \%)$. Diperkirakan 500.000 penduduk terkena stroke setiap tahunnya, sekitar 2,5\% atau 125.000 orang meninggal, dan sisanya cacat ringan hampir setiap hari, atau minimal rerata tiap hari ada seorang penduduk Indonesia, baik tua maupun muda meninggal dunia karena serangan stroke (PDPERSI, 2010).

Di provinsi bengkulu ditemukan 1.012 kasus Stroke pada tahun 2016. Hal ini dilakukan untuk pengukuran berbagai variabel kesehatan masyarakat dan hasilnya adalah Penyakit Stroke merupakan pembunuh utama dikalangan penduduk perkotaan. Stroke merupakan penyakit atau gangguan fungsional otak berupa kelumpuhan saraf akibat terhambatnya aliran darah ke otak. Stroke terjadi karena sumbatan (Stroke Iskemik) atau perdarahan (Stroke Hemoragik) (Junaidi, 2011). Peningkatan jumlah penderita Stroke ini identik dengan perubahan gaya hidup yaitu pola makan kaya lemak atau kolesterol sehingga dapat mempengaruhi peningkatan tekanan darah yang melanda di seluruh dunia, tak terkecuali Indonesia. Peningkatan tekanan darah dapat menyebabkan terjadinya stroke hemoragik, sehingga perlu untuk mengobsrvasi dan melakukan pengukuran tekanan darah untuk mencegah terjadinya stroke hemoragik serta mengurangi angka kematian (Yastroki, 2010).

Komplikasi stroke tergantung dari sisi atau bagian mana yang terkena, rata-rata serangan, ukuran lesi dan adanya peningkatan tekanan sirkulasi kolateral pada stroke, (Padila, 2012). Pada stroke akut komplikasi yang dialami adalah (1). kelumpuhan wajah atau anggota badan sebelah (hemiparesis) yang timbul secara mendadak, (2) gangguan sesibilitas pada satu atau lebih anggota badan. (3) penurun kesadaran. (4) Afasia. (5) Disatria. (6) gangguan diplopia. (7) Ataksia. (8) Vertigo. Hemiparese merupakan salah satu komplikasi yang akan dialami penderita stroke, dimana penderita stroke tidak mampu melakukan aktivitas mandiri, oleh sebab itu untuk mencegah terjadinya proses penyembuhan yang lama perlu dilakukan latihan agar dapat mengurangi gejala sisa stroke, latihan yang efektif untuk dilakukan pada pasien stroke selain fisioterapi adalah latihan ROM (Muttaqin, 2012).

Latihan Range Of Motion (ROM) merupakan salah satu bentuk latihan dalam proses rehabilitasi yang dinilai masih cukup efektif untuk mencegah terjadinya kecacatan pada pasien dengan stroke. Latihan ROM merupakan sekumpulan gerakan yang dilakukan pada bagian sendi yang bertujuan untuk meningkatkan fleksibelitas dan kekuatan otot (Potter \& Perry, 2010). ROM dapat diterapkan dengan aman sebagai salah satu terapi pada berbagai kondisi pasien dan memberikan dampak positif baik secara 
fisik maupun psikologis, latiahan ringan seperti ROM memiliki beberapa keuntungan antara lain lebih mudah dipelajari dan diingat oleh pasien dan keluarga mudah diterapkan dan merupakam intervensi keperawatan dengan biaya murah yang dapat diterapakan oleh penderita stroke.

Berdasarkan hasil survey awal yang dilakukan di RSUD Curup tahun 2016 sebanyak 118 orang, stroke hemoragik sebanyak 74 orang dan stroke non hemoragik sebanyak 44 orang dan pada tahun 2017 sebanyak 115 orang, stroke hemoragik sebanyak 27 orang dan stroke non hemoragik sebanyak 88 orang, tahun 2018 diperoleh penderita stroke sebanyak 120 orang dimana penderita stroke hemoragik sebanyak 35 orang dan stroke non hemoragik sebanyak 85 orang, dimana setiap hari perawat ICU RSUD Curup memberikan asuhan keperawatan sesuai dengan tingkat ketergantungan pasien, termasuk latihan ROM, ADL, personal hygiene (rekam medik RSUD Curup tahun 2106-2018).

\section{METODE PENELITIAN}

Metode yang digunakan dalam penelitian ini adalah nonquivalent control group design dan jenis penelitian ini adalah quasi eksperimen pre dan post with control group pada pasien stroke non hemoragik dengan hemiparese ekstremitas atas. Kedua kelompok tersebut kemudian dilakukan pretest, kemudian eksperimen atau intervensi hanya dilakukan pada kelompok subyek yang diteliti, sedangkan kelompok kontrol hanya diberi terapi standar prosedur ruangan. Penelitian ini dilaksanakan di Ruang ICU RSUD Curup pada bulan Juni- JuliTahun 2019. Populasi dalam penelitian ini adalah seluruh pasien stroke non hemoragik yang ada di Ruang ICU RSUD Curup.

Tehnik pengambilan sampel dengan menggunakn tehnik consecutive sampling dengan jumah sampel 20 responden. Kriteria inklusi dalam penelitian ini adalah bersedia menjadi responden, pasien dengan diagnosa stroke non hemoragik, hemiparese dan pasien dengan skala nyeri 0. Sedangkan kriteria eklusi dalam penelitian ini adalah pasien dengan stroke hemoragik dan pasien penurunan kesadaran (koma). Alat yang digunakan dalam penelitian ini adalah pedoman latihan ROM dan pedoman kekuatan otot. Cara pengumpulan data pada peneltian ini dengan cara observasi menggunakan pedoman latihan dan pedoman pengukuran kekuatan otot. terapi ROM dilakukan sebanyak 2x sehari selama 5 hari kemudian diukur kembali kekuatan otot post latihan pada kelompok intervnsi, pada kelompok kontrol dilakukan pengukuran hari pertama dan kemudian diukur kembali di hari ke-5 dan tidak dilakukan intervensi.

Analisa univariat dilakukan untuk melihat distribusi frekuensi kekuatan otot ekstermitas atas pasien stroke yang mendapatkan latihan ROM di Ruang ICU RSUD Curup. Sebelum dilakukan analisa bivariat, dilakukan uji normalitas yang merupakan syarat untuk uji $\mathrm{t}$ dependen dan independen. Pada penelitian ini menggunakan uji saphiro wilk karena jumlah responden $<50$ responden. Jika hasil normality shapirowilk, diperoleh hasil nilai kemaknaan untuk kedua kelompok data adalah > 0,05. Dengan demikian, dapat diambil kesimpulan bahwa distribusi kedua kelompok data adalah normal. Maka uji hipotesis yang digunakan adalah uji t berpasangan. Analisa yang digunakan untuk mengetahui hubungan antara variabel bebas dengan variabel terikat dengan menggunakan uji statistik. Analisa pada penelitian ini menggunakan Uji t digunakan untuk mengetahui pengaruh latihan ROM pasif terhadap kekuatan otot ekstermitas atas pasien stroke. 


\section{HASIL PENELITIAN}

Tabel. 1

Nilai Kekuatan Otot Ekstermitas Atas Sebelum (Pre-Test) pada Kelompok Intervensi dan Kelompok Kontrol

\begin{tabular}{ccccc}
\hline Variabel & \multicolumn{3}{c}{ Kelompok } \\
\hline \multirow{2}{*}{ Nilai kekuatan otot } & Mean & SD & Mean & Sontrol \\
(Pre-test) & 1,60 & 0,69 & 1,70 & 0,67 \\
\hline
\end{tabular}

Berdasarkan tabel 1 menunjukan bahwa nilai kekuatan otot sebelum (pre-test) pada kelompok intervensi memiliki nilai rata-rata 1,60 dengan standar deviasi 0,69, sedangkan pada kelompok kontrol sebelum dilakukan perlakuan (pre-test) memiliki nilai rata-rata 1,80 dengan standar deviasi 0,67 .

Tabel. 2

Nilai Kekuatan Otot Ekstermitas Atas Otot Sesudah (Post-test) pada Kelompok Intervensi dan Kelompok Kontrol

\begin{tabular}{ccccc}
\hline \multirow{2}{*}{ Variabel } & \multicolumn{2}{c}{ Intervensi } & \multicolumn{2}{c}{ Kelompok } \\
& Mean & SD & Mean & SD \\
Nilaikekuatanotot & 2,30 & 0,8 & 1,80 & 0,63 \\
(Post-test) & & & &
\end{tabular}

Berdasarkan tabel 2 menunjukan bahwa nilai kekuatan otot sesudah diberi latihan ROM (post-test) pada kelompok intervensi memiliki nilai rata-rata 2,30 dengan standar deviasi 0,8 sedangkan nilai kekuatan otot (post-test) pada kelompok kontrol memilik nilai rata-rata 1,80 dengan standar deviasi 0,63.

\section{Tabel. 3}

Pengaruh Latihan Range Of Motion (ROM) terhadap Kekuatan Otot Pre dan Post pada Kelompok Intervensi dan Kelompok Kontrol pada Pasien Stroke Non Hemoragik

\begin{tabular}{cccccc}
\hline \multirow{2}{*}{ Nilai kekuatan otot } & \multicolumn{2}{c}{ Pre-test } & \multicolumn{2}{c}{ Post-test } & $p$ value \\
& Mean & SD & Mean & SD & \\
\hline Kelompok kontrol & 1,80 & 0,63 & 1,70 & 0,67 & 0,5 \\
Kelompok intervensi & 1,60 & 0,69 & 2,30 & 0,83 & 0,008 \\
\hline
\end{tabular}

Berdasarkan tabel 3 diketahui perbedaan nilai mean pre-test dan post-tes pada kelompok intervensi dan kelompok kontrol dan diketahu nilai $p$ value pada kelompok kontrol adalah 0,5 sehingga dapat disimpulkan tidak ada pengaruh pada kelompok kontrol sedangkan pada kelompok intervensi $\mathrm{p}=0,008$ sehingga dapat disimpulkan terdapat pengaruh latihan ROM terhadap kekuatan otot.

Tabel. 4

Pengaruh Nilai Kekuatan Otot Ekstermitas Atas Sebelum dan Sesudah Kelompok Intervensi dan Kelompok Kontrol

\begin{tabular}{|c|c|c|c|c|c|}
\hline \multirow{3}{*}{$\begin{array}{c}\text { Nilai kekuatan } \\
\text { otot }\end{array}$} & \multicolumn{4}{|c|}{ Kelompok } & \multirow{3}{*}{$\mathrm{P}$} \\
\hline & \multicolumn{2}{|c|}{ Intervensi } & \multicolumn{2}{|c|}{ Kontrol } & \\
\hline & Mean & SD & Mean & SD & \\
\hline Pre-test & 1,60 & 0,69 & 1,80 & 0,63 & 0,55 \\
\hline Post-test & 2,30 & 0,82 & 1,70 & 0,67 & 0.28 \\
\hline
\end{tabular}


Berdasarkan tabel 4 dapat disimpulkan pada kelompok intervensi nilai $\mathrm{p}=0,28$ sedangkan pada kelompok kontrol nilai $\mathrm{p}=0,55$ sehingga dapat disimpulkan ada perbedaan yang bermakna dan diartikan bahwa ada pengaruh latihan ROM terhadap kekuatan otot.

\section{PEMBAHASAN}

Stroke atau CVA (Cerebro Vascular Accident) adalah kehilangan fungsi otak yang diakibatkan oleh berhentinya suplai darah kebagian otak. Stroke hemoragik adalah stroke karena pecahnya pembuluh darah sehingga menghambat aliran darah yang normal dan darah merembes kedalam suatu daerah otak dan merusaknya (Smeltzer \& Bare, 2013). Etiologi Stroke adalah Perdarahan intraserebral, Perdarahan Subarakhnoid, Perdarahan Serebral. Faktor risiko stroke beberapa faktor penyebab stroke antara lain Hipertensi, merupakan faktor risiko utama, Penyakit kardiovaskular-embolisme serebral berasal dari jantung, kolesterol darah tinggi. Obesitas atau kegemukan. Peningkatan hematokrit meningkatkan risiko infark serebral. Diabetes mellitus terkait dengan aterogenesis terakselerasi. Kontrasepsi oral (khususnya dengan hipertensi, merokok, dan kadar estrogen tinggi).

Manifestasi klinis stroke tergantung dari sisi atau bagian mana yang terkena, ratarata serangan, ukuran lesi dan adanya sirkulasi kolateral. Pada stroke akut gejala klinis meliputi kelumpuhan wajah atau anggota badan sebelah (hemiparesis) yang timbul secara mendadak, gangguan sensibilitas pada satu atau lebih anggota badan penurunan kesadaran (konfusi, delirium, letargi, stupor, atau koma), afasia (kesulitan dalam bicara), disatria (bicara cadel atau pelo), gangguan penglihatan, diplopia, Ataksia Vertigo, mual, muntah, dan nyeri kepala.

Berdasarkan hasil penelitian ini terdapat 20 responden dimana $10(50 \%)$ responden tidak mendapat latihan dan pada $10(50 \%)$ responden mendapat latihan ROM, dari 10 orang responden pada kelompok intervensi terdapat 7 (70\%) responden mengalami peningkatan kekuatan otot dan hanya sebagian kecil $3(30 \%)$ responden tidak mengalami peningkatan kekuatan otot. Sedangkan pada kelompok kontrol sebagian kecil $1(10 \%)$ yang mengalami peningkatan kekuatan otot dan sebagian besar 9 $(90 \%)$ responden tidak mengalami peningkatan kekuatan otot.

Hasil penelitian diperoleh nilai rata-rata kekuatan otot pre-test pada kelompok intervensi 1,60 dan nilai rata-rata kekuatan otot pada kelompok kontrol 1,80. Hal ini disebabkan karena pada penderita stroke memiliki komplikasi dan permasalahan yaitu terjadinya kelumpuhan separuh badan dan gangguan fungsional seperti gangguan gerak serta sensorik. Hal ini sesuai dengan konsep yang menyatakan bahwa gejala-gejala stroke yang umum terjadi adalah lumpuh sebelah/separuh badan (hemiparese), kesemutan, mulut mencong. Sehingga penderita stroke memiliki keterbatasan dalam melakukan pergerakan (Rahayu, 2015).

Hemiparese merupakan masalah umum yang dialami oleh pasien dengan stroke. Hemiparese pada ekstermitas atas dapat menyebabkan berbagai keterbatasan sehingga pasien stroke banyak mengalami ketergantungan dalam beraktivitas. Salah satu intervensi yang bisa dilakukan untuk mengatasi masalah hemiparese pada ekstermitas atas adalah dengan melakukan latihan ROM baik pasif maupun aktif (Muttaqin, 2012). Hasil penelitian menunjukan bahwa pada kedua kelompok, baik kelompok intervensi dan kelompok kontrol sebagian besar mengalami penurunan kekuatan otot.Hal ini sesuai dengan konsep yng menyatakan bahwa pasien stroke dapat mengalami hemiparese yang dapat ditandai dengan menurunnya kemampuan motorik pasien yang 
dapat diidentifikasi dari menurunnya kekuatan otot pasien. Pengukuran kekuatan otot dapat dilakukan dengan menggunakan pengujian otot secara manual yang disebut dengan MMT (Manual Muscle Test), pemeriksaan ini bertujuan untuk mengetahui kemampuan otot mengkontraksikan kelompok otot secara volunter (Yuliastuti et al., 2017). Hal ini sama halnya dengan yang dilakukan peneliti, dimana peneliti juga melakukan pemeriksaan otot dengan cara manuar, berdasarakan skala 0-5 yang dikemukakan oleh (Smeltzer \& Bare, 2013).

Pasien stroke yang mengalami kelemahan pada satu sisi anggota tubuh disebabkan oleh karena penurunan tonus otot, sehingga tidak mampu menggerakkan tubuhnya (imobilisasi). Immobilisasi yang tidak mendapatkan penanganan yang tepat, akan menimbulkan komplikasi berupa abnormalitas tonus, orthostatic hypotension, deep vein thrombosis dan kontraktur (Garrison, 2003). Lewis et al., (2007) mengemukakan bahwa atropi otot karena kurangnya aktivitas dapat terjadi hanya dalam waktu kurang dari satu bulan setelah terjadinya serangan stroke. Kontraktur merupakan salah satu penyebab terjadinya penurunan kemampuan pasien penderita stroke dalam melakukan rentang gerak sendi. Kontraktur diartikan sebagai hilangnya atau menurunnya rentang gerak sendi, baik dilakukan secara pasif maupun aktif karena keterbatasan sendi, fibrosis jaringan penyokong, otot dan kulit (Garrison, 2003).

Paralisis atau kelumpuhan disebabkan karena hilangnya suplai saraf ke otot sehingga otak tidak mampu untuk menggerakkan ekstremitas, hilangnya suplai saraf ke otot akan menyebabkan otot tidak lagi menerima sinyal kontraksi yang dibutuhkan untuk mempertahankan ukuran otot yang normal sehingga terjadi atropi. Serat otot akan dirusak dan digantikan oleh jaringan fibrosa dan jaringan lemak. Jaringan fibrosa yang menggantikan serat otot selama atrofi akibat denervasi memiliki kecenderungan untuk terus memendek selama berbulan bulan, yang disebut kontraktur. Atropi otot menyebabkan penurunan aktivitas pada sendi sehingga sendi akan mengalami kehilangan cairan sinovial dan menyebabkan kekakuan sendi. Kekakuan sendi dan kecenderungan otot untuk memendek menyebabkan penurunan rentang gerak pada sendi (Guyton \& Hall, 2007).

Hasil dari penelitian in diperoleh nilai rata-rata post-test diberi latihan ROM kelompok intervensi adalah 2,30 dengan standar deviasi 0,83 sedangkan nilai rata-rata post-test pada kelompok kontrol adalah 1,70 dengan standar deviasi 0,67. Hal ini terdapat peningkatan kekuatan otot pada kelompok intervensi sedangnkan pada kelompok kontrol tidak terjadi perubahan/peningkatan.Setelah dilakuakn latihan ROM pada kelompok intervensi terjadi peningkatan. Sesuai dengan konsep yang menyatakan latihan ROM merupakan salah satu bentuk latihan dalam proses rehabilitasi yang dinilai masih cukup efektif untuk mencegah terjadinya kecacatan pada pasien dengan stroke. Secara konsep, latihan ROM dikatakan dapat mencegah terjadinya penurunan fleksibelitas sendi dan kekakuan sendi (Lewis et al., 2017).

Penelitian yang dilakukan oleh Bakara \& Surani (2016) menunjukkan bahwa Latihan ROM pasif mempengaruhi rentang sendi pada ektremitas atas dan bawah pada pasien stroke. Latihan ROM pasif dapat menjadi alternatif untuk meningkatkan rentang sendi pada ektremitas atas dan bawah pada pasien stroke. Hasil analisis menunjukan ROM pasif yang dilakukan pada pasien stroke dapat meningkatkan rentang sendi, dimana reaksi kontraksi dan relaksasi selama gerakkan ROM pasif yang dilakukan pada pasien stroke terjadi penguluran serabut otot dan peningkatan aliran darah pada daerah sendi yang mengalami paralisis sehingga terjadi peningkatan penambahan rentang sendi abduksi-adduksi pada ekstremitas atas dan bawah hanya pada sendi-sendi besar. 
Sehingga ROM pasif dapat dilakukan sebagai alternatif dalam meningkatkan rentang sendi pada pasien stroke yang mengalami paralisis.

Pada kelompok kontrol tidak terjadi peningkatan kekuatan otot disebabkan pada kelompok kontrol tidak diberikan latihan dan hanya diberikan perlakuan ruangan, sehingga tidak terjadi pergerakan secara optimal pada sisi yang yang mengalami hemiparese pada pasien strok non hemoragik sehingga tingkat fleksibelitas dan mobilitas otot mengalami kekakuan. Hasil penelitian ini sesuai dengan penelitian yang dilakukan Marlina (2011) dimana tidak terjadi peningkatan kekuatan otot pada kelompok kontrol dengan nilai rata-rata 2,76 dengan standar deviasi 1,71. Pada pengukuran setelah intervensi diperoleh rata-rata 2,84 dengan standar deviasi 1,79. Terdapat perbedaan nilai mean antara pengukuran pertama dan kedua adalah 0,80 sehingga tidak terjadi peningkatan kekuata otot pada kelompok kontrol. Hasil penelitian ini sesuai dengan konsep yang menyatakan latihan ROM dapat memeprtahankan fleksibelitas dan mobilitas sendi, mengembalikan kontrol motorik, menurunkan pembentukan kontraktur terutama pada ekstermitas yang mengalami paralisis atau hemiparese serta mencegah bertambah buruknya sistem neuromuscular (Smeltzer \& Bere, 2013).

Hasil penelitian ini juga menunjukan nilai rata-rata kekuatan otot pada kelompok intervensi sebelum dilakukan latihan ROM adalah sebesar 1.60, sedangkan rata-rata kekuatan otot sesudah diberi latihan ROM pada kelompok intervensi adalah sebesar 2,30, dan nilai $\mathrm{p}=0,008(<0,05)$. Nilai kekuatan otot kelompok kontrol sebelum sebesar 1,80 dengan standar deviasi 0,63dan sesudah (post-test) sebesar 1,70 dengan standar deviasi 0 ,67.Nilai $\mathrm{p}=0,5 \quad(\mathrm{P}>0,05)$ sehingga dapat disimpulkan adanya perbedaan antara kekuatan otot pre-test dan post-test pada kelompok intervensi sedangkan pada kelompok kontrol tidak ada perbedaan antara nilai pre-test dan post-tes. Stroke merupakan penyakit motor neuron yang dapat mengakibatkan kehilangan kontrol volunter terhadap gerakan motorik, salah satu masalah yang berhungan dengan motorik adalah hemiparese. Hemiparese atau kelemahan otot salah satu sisi tubuh adalah tanda lain yang sering ditemukan pada pasien stroke selain hemiolegi (Smeltzer \& Bare, 2013). Manifestasi dari hemiparese yang paling umum adalah menurunnya kekuatan otot. Kekuatan otot sangat berhubungan dengan sistem neuromuscular yaitu seberapa besar kemampuan sistem syaraf mengaktivasi otot untuk melakukan kontraksi. Dengan demikian semakin banyak serabut otot yang teraktivasi, maka semakin besar pula kekuatan yang dihasilkan oleh otot tersebut. Dimana kekuatan adalah kemampuan otot menahan beban baik berupa beban eksternal maupun beban internal (Irfan, 2012). Disfungsi pada ekstermitas atas yang dialami oleh pasien stroke merupakan gangguan fungsional yang paling umum terjadi, kelemahan otot (hemiparese) pada ekstermitas memiliki peranan yang besar dalam pemenuhan kebutuhan sehari-hari (Zeferico \& Aycock, 2010).

Latihan ROM merupakan salah satu bentuk latihan dalam proses rehabilitasi yang dinilai masih cukup efektif untuk mencegah terjadinya kecacatan pada pasien dengan stroke. Latihan ROM merupakan sekumpulan gerakan yang dilakukan pada bagian sendi yang bertujuan untuk meningkatkan fleksibelitas dan kekuatan otot (Potter \& Perry, 2010). ROM dapat diterapakan dengan aman sebagai salah satu terapi pada berbagai kondisi pasien dan memberikan dampak positif baik secara fisik maupun psikologis, latiahan ringan seperti ROM memiliki beberapa keuntungan antara lain lebih mudah dipelajari dan diingat oleh pasien dan keluargamudah diterapakan danmerupakam 
intervensi keperawatan dengan biaya murah yang dapat diterapakan oleh penderita stroke (Bakara \& Surani, 2016).

Hasil penelitian ini didukungoleh penelitian Cahyati et al., (2011) didapatkan hasil bahwa kekuatan otot meningkat setelah dilakukan latihan ROM baik unilateral dan bilateral, terdapat perbedaan antara latihan ROM unilateral dan bilateral, dimana latihan ROM bilateral lebih baik dalam meningkatkan kekuatan otot dibandingkan latihan ROM bilateral. Hal ini dibuktikan dengan hasil penelitian dimana kelompok intervensi I (latihan ROM unilateral) sebelum dilakukan latihan diperoleh nilai rata-rata kekuatan otot 1,93 dan setelah dilakukan latihan ROM diperoleh nilai rata-rata kekuatan otot 3.13, sedangkan pada kelompk II (latihan ROM bilateral) sebelum dilakukan latihan diperoleh nilai rata-rata kekuatan otot 2,07 sedangkan setelah dilakukan latihan ROM diperoleh nilai rata-rata kekuaan otot 4.20.

Hasil penelitian ini sesuai dengan penelitian yang dilakukan oleh Astrid et al., (2011) didapatkan hasil bahwa kekuatan otot meningkat dan kemampuan fungsional meningkat secara signifikan setelah diberikan latihan. Hal ini berarti latihan ROM berpengaruh terhadap peningkatan kekuatan dan kemampuan fungsional pasien stroke dengan hemiparese.

Penelitian serupa dilakukan oleh Puspitawati (2010) melakukan perbandingan antara latihan ROM 2 kali sehari dengan latihan ROM 1 kali sehari, dari hasil penelitian didapatkan bahwa latihan ROM 2 kali sehari lebih efektif meningkatkan kekuatan otot dibandingkan dengan latihan ROM 1 kali sehari.

\section{SIMPULAN}

Ada pengaruh latihan range of motion (ROM) terhadap kekuatan otot ekstermitas atas pasien stroke non hemoragik di Ruang ICU RSUD Curup tahun 2019.

\section{SARAN}

\section{Untuk RSUD Curup}

Diharapkan hasil penelitian ini dapat menjadi acuan dalam meningkatkan kaulitas mutu dalam memberikan pelayanan dan perawatan serta dapat dijadikan pedoman untuk bias membarikan latihan ROM pada setiap pasien stroke yang mengalami hemiparese dan membutuhkan rehabilitasi dalam pemulihan kontraktilitas otot.

\section{Untuk FIKES Dehasen Bengkulu}

Hasil penelitian ini diharapkan dapat menjadi sumber informasi dan sumber pustaka yang diperlukan oleh mahasiswa FIKES Dehasen Bengkulu dan dapat bermanfaat serta dapat digunakan sebagaimana mestinya.

\section{Untuk Peneliti Lain}

Diharapkan dapat mengembangkan lebih lanjut penelitian ini dengan factor lain yang dapat menimbulkan pengaruh terhadap peningkatan kekuatan otot pada pasien stroke dengan hemiparese. 


\section{DAFTAR PUSTAKA}

Aini, A., \& Purwaningsih, P. (2013). Pengaruh Alih Baring terhadap Kejadian Dekubitus pada Pasien Stroke yang Mengalami Hemiparesis di Ruang Yudistira di RSUD Kota Semarang. Http:/perpusnnwu.web.id

American Heart Association. (2010). Heart Deases and Stroke Statistic: Our Guide to Current Statistics and the Suplement to Our Heart and Stroke Fact 2010 Update. http://www.americanheart.org. Diakses pada tanggal 2 Desember 2018

Astrid, M., Elly, E., \& Budianto, B. (2011). Pengaruh Latihan Range of Motion (ROM) terhadap Kekuatan Otot, Luas Gerak Sendi dan Kemampuan Fungsional Pasien Stroke di RS Sint Carolus Jakarta. Jurnal Ilmu Keperawatan dan Kebidanan, 1(4), $175-182$

Bakara, B., \& Surani, S. (2016). Latihan Range Of Motion (Rom) Pasif terhadap Rentang Sendi Pasien Pasca Stroke. Idea Nursing Journal, 7(2), 12-18

Cahyati, Y., Nurachmah, E., \& Hastono, S. P. (2013). Perbandingan Latihan ROM Unilateral dan Latihan ROM Bilateral terhadap Kekuatan Otot pada Pasien Hemiparese akibat Stroke Iskemik di RSUD kota Tasik Malaya. Jurnal Keperawatan Indonesia, 16(1), 40-46

Dinata, C. A. (2010). Gambaran Factor Risiko dan Tipe Stroke pada Pasien Rawat Inap Bagian Penyakit Dalam RSUD Kabupaten Solok Selatan periode 1. http://jurnal.Fk.unand.ac.id/articles/volum2no_2/57-61.pdf. Diakses tanggal 1001-2019

Garrison, S. J. (2003). Handbook of Physical Medicine and Rehabilitation. Edisi II. Philadelphia: Lippincott Williams \& Wilkins

Guyton, C. A., \& Hall, J. E. (2007). Buku Ajar Fisiologi Kedokteran. Jakarta: EGC

Irfan, M. (2012). Fisioterapi bagi Insan Stroke. Yogyakarta: Graha Ilmu

Junaidi, I. (2011). Stroke A-Z. Jakarta : PT Bhuana Ilmu Populer

Lewis, S. L., Bucher, L., Margaret, M., Marrian, M., Kwong, J., \& Roberts, D. (2017). Medical-Surgical Nursing, 10th Edition. Mosby ElsevierInc

Marlina, M. (2011). Pengaruh Latihan ROM terhadap Peningkatan Kekuatan Otot pada Pasien Stroke iskemik di RSUDZA Banda Aceh. Idea Nursing Journal, III(1), 1120

Muttaqin, A. (2012). Pengantar Asuhan Keperawatan dengan Gangguan Sistem Persyarafan. Jakarta: Salemba

Padila, P. (2012). Buku Ajar Keperawatan Medikal Bedah. Yogyakarta: Nuha Medika

PDPERSI. (2010). Stroke, Penyebab Utama Kecacatan Fisik. http://pdpersi.co.id

Potter. P. A. \& Perry,A.G. 2010. Buku Ajar Fundamental Keperawatan: Konsep, Proses dan Praktek. Jakarta: EGC

Puspitawati, E. Y. (2010). Perbedaan Efektivitas ROM 2x Sehari dan ROM $1 x$ sehari

Rahayu, K. I. N. (2015). Pengaruh Pemberian Latihan Range Of Motion (ROM) terhadap Kemampuan Motorik pada Pasien Post Stroke di Rsud Gambiran. Jurnal Keperawatan, 6(2), 102-107

Riskesdas. (2013). Riset Kesehatan Dasar. Jakarta: Kementrian Kesehatan RI

Smeltzer, S., \& Bare, B. (2013). Brunner \& Suddarth's Textbook of Medical Surgical Nursing. Philadelpia: Lippincott

Yastroki, Y. (2010). Angka Kejadian Stroke Meningkat Tajam. (diakses2 februari 2018) diunduh dari : http://www.yastroki.sor.id 
Yuliastuti, R. A., Handayani, H., \& Kartini, Y. (2018). Perubahan Kemampuan Komunikasi Verbal Pasien Stroke iskemik dengan Disartria Pasca Lsvt loud di RSI Jemursari Surabaya. Jurnal Ilmiah Keperawatan (Scientific Journal of Nursing), 4(2), 108-116. https://doi.org/10.33023/jikep.v4i2.183

Zeferico, S. I., \& Aycock, D. M. (2010). Post Stroke Shoulder Pain: Inevitable or Preventable? Rehabilitation Nursing, 35(4), 47-51. DOI: 10.1002/j.20487940.2010.tb00040.x 